\title{
Students' Social Care During the COVID-19 Pandemic: How Do School and Family Make Collaboration to Develop it?
}

\author{
Rahmat Aziz ${ }^{*}$, M. Samsul Hady², Ai Rinda Novezry33, Selina Rahmawati Siswoyo4, \\ Mohammad Hasan Mustofa ${ }^{5}$ \\ ${ }^{1}$ Psychology Department of State Islamic University of Maulana Malik Ibrahim Malang, Indonesia \\ ${ }^{2}$ Islamic Education Department of State Islamic University of Maulana Malik Ibrahim Malang, Indonesia \\ 3,4,5 Post Graduate Program of State Islamic University of Maulana Malik Ibrahim Malang, Indonesia
}

\section{A R T I CL E I N F O}

Article history:

Received July 19, 2021

Revised July 20, 2021

Accepted October 24, 2021

Available online November 25, 2021

\section{Kata Kunci :}

Character Education

Collaboration,

Social Care

Keywords:

Pendidikan Karakter, Kolaborasi, Kepedulian Sosial

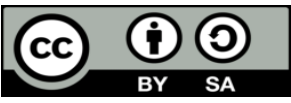

This is an open access article under the $\underline{C C}$ BY-SA license.

Copyright (c) 2021 by Author. Published by Universitas Pendidikan Ganesha

\begin{abstract}
A B S T R A K
Pembelajaran di masa pandemi COVID-19 menyebabkan kesulitan yang belum teratasi oleh pihak sekolah dan keluarga, gagalnya mengembangkan karakter peduli sosial pada siswa. Kehadiran guru yang belum siap mengajar secara online karena kemampuan dan fasilitas yang tidak memadai Kegiatan pembelajaran untuk mengembangkan Peduli Sosial Siswa selama masa COVID-19 telah menimbulkan berbagai kesulitan bagi guru, orang tua, dan siswa. Tantangan yang tidak ditanggapi secara tepat oleh sekolah dan keluarga mengakibatkan rendahnya karakteristik kepedulian sosial. Tulisan ini bertujuan untuk mendeskripsikan karakter peduli sosial siswa dan menganalisis peran sekolah (guru) dan keluarga (orang tua) selama proses pembelajaran. Makalah ini adalah penelitian tentang data yang dikumpulkan melalui kuesioner terbuka dan wawancara online. Kuesioner terbuka diberikan kepada 24 siswa dari tiga SMA di Malang, Provinsi Jawa Timur. Selain itu, data juga diperoleh dari sepuluh guru dan sembilan orang tua. Guru dan orang tua mengalami kesulitan dalam mengembangkan karakter peduli sosial, sehingga mengakibatkan rendahnya karakter peduli sosial siswa. Pemilihan model pembelajaran yang sesuai di masa pandemi dan kerjasama yang harmonis antara sekolah dan keluarga menjadi penentu keberhasilan dalam proses pembelajaran karakter peduli sosial siswa. Dengan demikian, proses pembelajaran online harus mengubah pola pikir guru dan orang tua bahwa proses pembelajaran yang berpusat pada guru tidak cocok untuk proses pembelajaran berbasis siswa sebagai pelaku pembelajaran yang memiliki otoritas untuk mencari dan menghasilkan pengetahuan.
\end{abstract}

\begin{abstract}
A B S T R A C T
Learning during the COVID-19 pandemic has caused difficulties that have not been resolved by the school and family, failing to develop social care characters in students. The presence of teachers who are not ready to teach online due to inadequate abilities and facilities Learning activities to develop Students' Social Care during the COVID-19 period have created various difficulties for teachers, parents, and students. Challenges that are not responded to appropriately by schools and families have resulted in low social care characteristics. This paper aimed to describe the social care character of students and analyzed the role of schools (teachers) and families (parents) during the learning process. This paper is research on data collected through an open questionnaire and online interviews. An open questionnaire was given to 24 students from three high schools in Malang, East Java Province. In addition, data were also obtained from ten teachers and nine parents. Teachers and parents have difficulty developing social care characters, resulting in the students' low social care character. The selection of the suitable learning model during the pandemic and harmonious cooperation between schools and families become a determinant of success in the learning process of students' social care characters. Thus, the online learning process should change the mindset of teachers and parents that the teacher-centred learning process is not suitable for a student-based learning process as learning actors who have the authority to seek and produce knowledge.
\end{abstract}

\section{INTRODUCTION}

Learning during the COVID-19 pandemic has caused difficulties that have not been resolved by the school and family, failing to develop social care characters in students. The presence of teachers who are not ready to teach online due to inadequate abilities and facilities (Wahyuni et al., 2021). Parents feel more burdened with roles at home (Israhadi, 2020). This condition results in many students experiencing a decline in mental health (Liu \& Doan, 2020). Many students become increasingly indifferent to the social world around them due to the necessity to stay more at home (Laili \& Nuryono, 2015). This condition necessitates the importance of proper handling by both schools and families so that the development of 
social care characters in students can grow and develop optimally (Dewi \& Alam, 2020). The social care character of students is the attitudes and actions of students in assisting people in need. This character is essentially a human need as a social being. Students need the essence of social care as a provision to live in their social environment (Chowdhury, 2018). Online learning currently makes it difficult for social care characters to develop because of the limited direct social interaction, even though social interactions between students are essential in the character development process (Wijayanto et al., 2020). Some data shows that the online learning process has resulted in students being less prosocial (Bhavya et al., 2021); lacking empathy for others (Nurhidayati \& Indrawadi, 2020); and less caring with others (Sutarini et al., 2015).

Teachers have a significant role in efforts to develop social care characters. There are three types of teacher roles in developing social care. First, the teacher acts as a source of information. Second, the teacher serves as an example. Third, the teacher acts as an evaluator who can control student behaviour at school (Setyaningrum et al., 2020). These three roles changed with the arrival of the Covid-19 Pandemic. The research found that teachers had negative opinions and thoughts about the educational process due to COVID-19 (Karakaya et al., 2021). The teacher revealed various difficulties experienced, including the loss of the emotional relationship between teacher-students, job uncertainty, economic losses, inadequate technological infrastructure, and teacher competence related to distance education. Learning activities at home during the pandemic allow parents to have many opportunities in helping children's learning success, including the development of social care characters. However, not all parents have the chance to make it happen. Factors that limit the provision of facilities to support online learning, their busy schedule to spend time accompanying children while studying at home and the lack of time they have to monitor children are some of the causes (Drane et al., 2020; Spinelli et al., 2020). The number of problems in online learning, especially in the development of students' social care characters because the limitations faced by parents make students increasingly uncontrollable both from material achievement or good character formation in learning objectives.

There are two types of studies on the development of social care characters in students. First, examinations of the social care result from a learning process, both studies conducted experimentally (Niraha et al., 2020) and non-experimental (Dangin et al., 2019). Second, social care studies result from an academic condition, both in the school environment (Dangin et al., 2019; Rahmawati et al., 2020) or teacher behaviour and characteristics (Yuliyanto et al., 2018). The two categories of research show that the teacher can develop social care in students. This research elaborates the second research model by including the role of schools and parents in learning social care for students. This study on the development of social care characters in students during the COVID-19 pandemic is based on an argument that schools and families have an essential and strategic role in developing social care characters. Teachers who act as directors and are responsible for the continuity of the educational process become important in the educational process during a pandemic. Likewise, as actors who deal directly with students at home, parents have a strategic role in achieving learning objectives.

\section{METHODS}

The research approach is qualitative research with a multi-case type sourced from primary data from informants from three in East Java. Preliminary data were obtained from field studies that aimed to get data about the phenomenon of social care character in students and the phenomenon's factors. The form of social care character is obtained through an open questionnaire analysis given online to students. Factors that affect the social care character of students are accepted by teachers and parents of students who come from the three schools. The selection of the three schools as research sites was based on information that the three schools had a privilege in implementing character education. In addition, the ease of access to the three places is another reason so that researchers find it easier and more in-depth to obtain the required data. The selection of cases regarding educational practices during the COVID-19 pandemic in developing social care characters with three critical considerations. First, social care is an essential aspect to be designed, so research on this theme still requires much elaboration. Second, failure to develop the character will fail in other parts. Third, the loss of the learning process in creating these characters necessitates an alternative learning model that can be used as a solution. The three reasons for choosing social care as an issue studied in this paper indicate the hope of finding solutions to problems in education and development that are solutive and innovative, especially in implementing character education for students at the high school level.

The data were obtained from 24 students, ten teachers and nine parents. The information from a student was obtained through questions in an open questionnaire through the google form facility and online interviews. The questions posed to students consisted of 2 themes related to the form of care 
behaviour and the reasons students carried out the behaviour. The data obtained from the teacher and parent were obtained through online interviews by focusing on questions about online learning and the efforts made in dealing with problems in developing students' social care characters during the COVID-19 pandemic. Data analysis was carried out using two essential stages in the data analysis process (Miles et al., 2014). The first stage is simplifying data about forms of social care obtained from questions given to students and data about difficulties in the learning process obtained from teachers and parents; displaying the data after a reduction so that the form becomes more straightforward to understand. In this process, the classification of similar data is carried out in a particular category group; and testing the completeness and validity of the data so that the data analyzed is valid and reliable. The second stage is interpreting the findings in the field to understand the meaning obtained from the field data. Researchers carry out the interpretation process through critical and reflective in-depth analysis

\section{RESULT AND DISCUSSION}

\section{Results}

The research was conducted in three schools in East Java. There are: Islamic high school Hasyim Asy'ari in Batu. This school teaches all subject matter following the required curriculum by adding subject matter related to Islam. This school organizes various extracurricular activities that aim to support character building in students. High school of Al-Rifa'ie in Gondanglegi. This school has a vision of realizing students who excel in science and technology-based on morality. This school is part of educational activities in Islamic boarding schools. High school of Baitul Akhyar in Lawang. This school aims to produce graduates of the Qur'an generation who have competence in scientific expertise. This school is under the auspices of the Baitul Karim Islamic. The data of this study were obtained from four data sources, namely students, teachers, and parents of students. Data from students in the form of a description of the character of students' social care. Data from teachers and parents are based on views on implementing character education during the COVID-19 pandemic and overcoming these difficulties. Complete data regarding the in Table 1.

Tabel 1. The Informant

\begin{tabular}{|c|c|c|c|c|c|c|c|c|c|}
\hline \multirow{2}{*}{ School names } & \multicolumn{3}{|c|}{ Student } & \multicolumn{3}{|c|}{ Teacher } & \multicolumn{3}{|c|}{ Parent } \\
\hline & Male & Female & Total & Male & Female & Total & Male & Female & Total \\
\hline $\begin{array}{l}\text { Senior high school of } \\
\text { Baitul Akhyar }\end{array}$ & 10 & 0 & 10 & 2 & 1 & 3 & 0 & 3 & 3 \\
\hline $\begin{array}{l}\text { Senior high school of } \\
\text { Al-Rifa'ie }\end{array}$ & 0 & 3 & 3 & 1 & 2 & 3 & 0 & 3 & 3 \\
\hline $\begin{array}{l}\text { Senior high school of } \\
\text { Hasyim Asy'ari }\end{array}$ & 7 & 4 & 11 & 2 & 2 & 4 & 0 & 3 & 3 \\
\hline Total & 17 & 7 & 24 & 5 & 5 & 10 & 0 & 9 & 9 \\
\hline
\end{tabular}

Table 1 explains that the three schools used as research sites are private high school levels that develop Islamic character. The number of female subjects in students is more than the number of males. The parents' issues in the three schools were all women, so the parents' opinion in accompanying children to study at home was the mothers' perception.

\section{Description of the student's character of social care}

In this section, a description of the social care character of students is shown, which is obtained through answers to open questions. This question was given to 24 students from three schools. This indication is obtained from the subject's responses when giving "rare" answers to some of the questions. Furthermore, the issue is analyzed about socially indifferent behaviour and the reasons for providing the solution. The answers are grouped into three categories, and the frequency and percentage of the responses are calculated. The complete data show in Table 2.

Table 2 explains that there are three forms of social indifference that are displayed in three forms of student behaviour. First, the lack of prosocial attitudes is shown by behaviours such as not wanting to help friends and reluctance to participate in social activities. Second, the lack of empathy for other people's difficulties, for example, the attitude of letting others in their troubles without trying to help. Third, less concerned with the world around them, for example, the behaviour of students who feel cool with themselves. These three behaviours show that they have a low character in terms of social care. These data are in line with the results of interviews with several students who stated that .... I cannot do prosocial 
activities because I live in a pesantren environment, so I have a lot of work to do (Subj.01). Another student stated that my friend has adequate facilities so that he does not need my help (Subj.12). Another student said that ... I feel that the friendship that exists between us is not deep enough so that we feel less empathy towards our friends (Subj.15).

Tabel 2. The student's character of social care

\begin{tabular}{lllll}
\hline No. & Question & Finding & $\Sigma$ & \% \\
\hline 1 & Forms of student social care & Less of prosocial & 15 & 62 \\
& behaviour & Less of empathy & 6 & 25 \\
& & Les of sympathy & 3 & 13 \\
& & & 24 & 100 \\
2 & \multirow{2}{*}{ Reasoning } & lazy & 9 & 38 \\
& & Not interesting with others & 10 & 42 \\
& & Busy with their self & 5 & 20 \\
& & 24 & 100 \\
\hline
\end{tabular}

\section{The role of the teacher in online learning}

This section presents an overview of the teacher's difficulties obtained through answers to online questions. Questions to the teacher focused on the problems of teachers in the online learning process in developing caring social characters in students? What were efforts made to overcome these difficulties? Data from 10 teachers. The answers were grouped into three categories, and the number of frequencies and percentages of the responses. The complete data show in Table 3.

Table 3. Teacher difficulties in online learning

\begin{tabular}{lllcc}
\hline No & Question & Finding & $\boldsymbol{\Sigma}$ & $\mathbf{\%}$ \\
\hline 1 & Online learning problem & Limited facilities & 8 & 80 \\
& & Difficulty teaching subject matter & 1 & 10 \\
& & Low Student's response & 1 & 10 \\
\multirow{2}{*}{2} & \multirow{2}{*}{ Efforts to solve problems } & Monitoring students more intensively & 10 & 100 \\
& & Forming online study groups & 6 & 60 \\
& & Maximize use of facilities & 2 & 20 \\
& & & 2 & 20 \\
\hline
\end{tabular}

Table 3 describes the three types of difficulties experienced by the school. First, the limited facilities, especially the problem of the internet network owned by the school. This data shows that the readiness of infrastructure is the main obstacle in the online learning process. Second, the difficulty in delivering the subject matter online. These data indicate that the competence of teachers in implementing the learning process still needs to be developed. Third, it isn't easy to monitor student behaviour. These data indicate that teachers' understanding of learning is still conventional, which assumes that students must be observed directly. These three difficulties suggest that they have problems in the professional aspect to require development in their professional field. These data are consistent with the results of interviews with three teachers in three different schools. One of the teachers related to the difficulty of the online learning process stated that.... One of my difficulties in teaching is the ability to monitor the learning process at home, and many students cannot focus on the lesson (Subj. 03). Another teacher added that.... The most severe difficulty I feel is the problem of available internet network facilities. So what I did was to create study groups among students (Subj. 04). Another teacher stated that ... I felt that the online learning process was monotonous and mainly in giving homework to feel bored (Subj. 08).

\section{The role of parents in online learning}

In this section, a description of the parents' difficulties is presented, obtained through the answers to the questions given online. Our questions focused on what are the problems for parents in accompanying children during the online learning process? What were efforts made to overcome these difficulties? What are the expectations of parents in facing the current conditions? Data were obtained from 9 parents. The answers given are then grouped into three categories, and the number of frequencies and percentages of the responses are calculated. The complete data is shown in Table 4.1 
Table 4. Parent difficulties in online learning

\begin{tabular}{lllll}
\hline No & Question & Finding & $\mathbf{2}$ & $\mathbf{\%}$ \\
\hline 1 & Online learning problem & Limited facilities & 4 & 44,4 \\
& & Having a busy household & 3 & 33,3 \\
& & Understanding the subject matter & 2 & 22,2 \\
& & & 9 & 100 \\
2 & \multirow{2}{*}{ Efforts to solve problems } & Taking time to help children & 4 & 44,4 \\
& & Guiding learning in children & 3 & 33,3 \\
& & Maximizing the use of existing facilities & 2 & 22,2 \\
& & & 9 & 100 \\
\hline
\end{tabular}

Table 4 describes the three types of difficulties experienced by parents in accompanying their children at home. First, the limitations of facilities, especially the problem of the family-owned internet network. Second, the difficulty in understanding the subject matter that children must study. Third, the difficulty of dividing time due to other activities that must be completed. The three problems indicate that they have challenges that affect students' quality of social care character. The data is in line with parents' opinion who stated that ... I cannot monitor my child every day because I also have other activities. but if there is a problem, I usually consult with the teacher (Subj. 02). Other parents expressed almost the same opinion that there were other things to do. She stated that... I divided the duties with my husband to accompany the children (Subj. 04). Another subject expressed a slightly different opinion; she said that ... the price of the internet quota was high, so I had to save money to meet the learning needs of children.

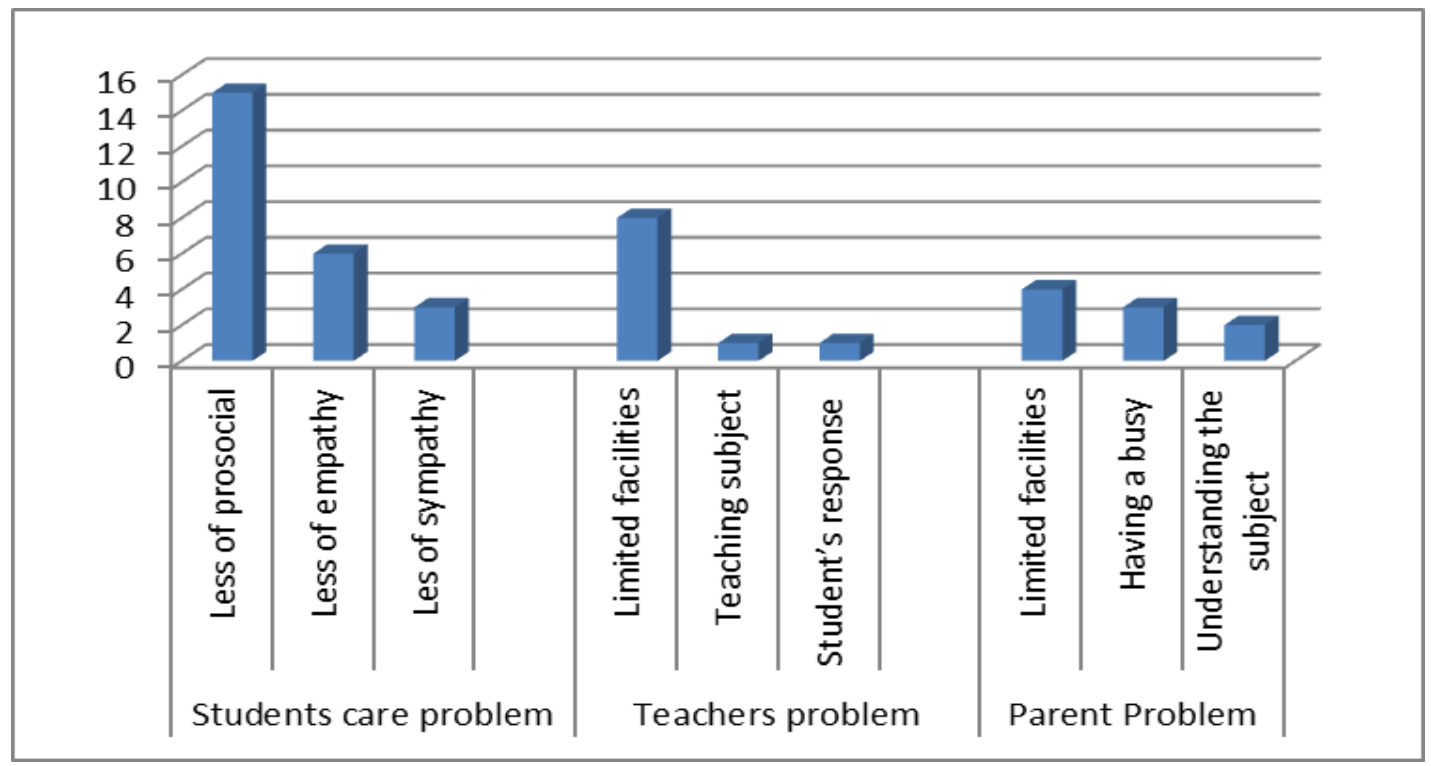

Figure 1. The learning problem of social care characters

Figure 1 explains that this study found three problems related to character education. First, there is a problem with students' low social care characterized by a lack of prosocial behaviour, a lack of empathy, and a lack of sympathy. Second, teachers experience difficulties in the learning process, especially in limited facilities, learning methods used, and monitoring student responses. Third, parents have a problem assisting their children in studying at home, especially in terms of their facilities, busyness in the household, and difficulties in understanding the subject matter that students must learn.

\section{Discussion}

The results of this study indicate there are problems related to the character of social care in students. Online learning that takes place has a significant role in creating conditions that make children feel uncomfortable. Students become less cooperative towards teachers and parents due to boredom and pressure (Mulia, K., Hurley, P. \& Macklin, 2020). In addition to the many tasks given by the teacher (Deliviana et al., 2021; Muchsini \& Siswandari, 2020). These conditions indicate the importance of handling students as subjects and objects in the ongoing learning process. This study shows that the study of the social care character of students conducted is different from the previous one. This study found various 
forms of low social care behaviour in students and found the background of the behaviour being carried out. These results also reflect the failure of the online learning process in developing social awareness in students. The low level of student awareness will result in various student life in the future. The study found that students who had low levels of social awareness correlated with low levels of academic ability (Dangin et al., 2019). Another similar study found that empathy as an indicator of social care behaviour was negatively correlated with the level of student aggressiveness (Waya \& Siti, 2017). Conditions like this can be overcome when teachers and parents can solve the problems experienced by students.

Data showing the various difficulties experienced by teachers have implications for multiple aspects related to the learning process. The research found that the obligation of students to study at home is the same as reducing student and teacher communication in building an academic culture so that feedback in the learning process is reduced. The learning process is not carried out effectively because of students' lack of understanding of the material presented and the inadequate response of students in learning (Carrillo, C., \& Flores, 2020; Karakaya et al., 2021). This study shows that there have been many studies on the role of teachers in online learning, but this study has significant differences. This study found the difficulties of teachers in teaching social care behaviour to students during online learning. This study was also able to find various teacher efforts in overcoming these difficulties. The results of this study reflect the importance of developing the insight and skills of teachers in carrying out their profession. Several research models on teacher development have been carried out. For example, developing insight into the teaching profession, developing teaching skills and skills in classroom action research (Arifa \& Prayitno, 2019; Mumpuniarti et al., 2020). This development model can be an alternative in teacher development efforts, especially the teacher development model in improving the ability to use technology in the online learning program.

The results of this study indicate that the difficulties experienced by parents in accompanying their children to study at home have become a serious problem that results in the quality of students' social care characters. Several studies have shown the importance of the role of parents in forming children's character (Paul et al., 2020; Setiadi et al., 2020). During the COVID-19 Pandemic, parents have a lot of time to guide their children to make emotional closeness possible more than ever. This study shows that there have been many studies on the role of parents in online learning, but this study has significant differences. This study found parents' difficulties in playing their role as teachers at home in developing social care behaviour in students during the COVID-19 pandemic. This research was also able to find various parents' efforts in overcoming these difficulties. The results of this study reflect that education is a shared responsibility not only for schools (teachers) but also the role of the family becomes essential (Al Hakim, 2021; Sukarman, 2020). The role of parents in the learning system during this pandemic is strategic and urgent. Both father and mother are at the forefront of guarding their children to continue studying at their respective homes. A possible explanation for this might be that the degradation of students' character indicates a severe problem in character education. This problem is not only the responsibility of the teacher as an educator. (Kim et al., 2018; Lonto et al., 2018) but also the responsibility of parents as a companion for children in learning at home (Paul et al., 2020; Singh, 2019). One of the issues that emerge from these findings is the importance of cooperation between teachers and parents in the character learning process. Teachers deliver learning materials to students and act as mentors for parents who need help understanding the subject matter. Parents not only assist students in learning but also must understand the psychological condition of children when experiencing difficulties and boredom in learning.

The results of this study reflect that education is a shared responsibility between teachers and parents. Heavy burdens and responsibilities in carrying out education should not be left only to teachers or parents, but must be a shared responsibility between the two. The existence of various difficulties for teachers and parents that result in the low quality of student character has necessitated the importance of cooperation (Aouad \& Bento, 2020; Myende \& Nhlumayo, 2020). The collaboration built by both parties, apart from being able to lighten the existing burden, is also able to be a solution to answer challenges in developing various aspects of student life. The failure of the learning process in developing students' character has shown that there are two important meanings for education. First, education that only emphasizes teachers or parents has become a heavy burden for both parties. Second, the harmonious collaboration model between teachers and students is an alternative for achieving educational goals (Äärelä et al., 2018).

These findings may help us understand the importance of harmonious collaboration between schools and families in developing students' social care characters. Collaboration between teachers and parents through efforts to understand each other and help each other carry out their respective roles (Borg \& Pålshaugen, 2019). Teachers not only act as teachers of subject matter to students, but they must also be a source of information for parents who need information assistance in educating at home. Likewise, with the role of parents, they take care of problems related to the household, but they must be able to replace the 
part of teachers in assisting children in studying at home. This research is limited to online data, either through questionnaires given to students or direct interviews with schools and families. The technique of collecting data through observation, an essential method in qualitative research, was not used because of the pandemic conditions that made it impossible to do. Likewise, the informants' views as the basis for implementing social care character learning in students still do not reflect in-depth data. Based on these limitations, further research needs to be carried out by paying attention to data collection techniques and selecting more appropriate informants.

\section{CONCLUSION}

An essential finding of this study shows that the low character of social care in students is caused by difficulties from both the school and the family in carrying out online learning. These findings indicate a social transformation in educational practice that teachers and parents do not yet understand. Academic preparation, which has been understood as a one-way process of providing information, has become an interactive process involving various parties. Thus, the online learning process should change the mindset of teachers and parents that the teacher-centred learning process is not suitable for a student-based learning process as learning actors who have the authority to seek and produce knowledge.

\section{REFERENCES}

Äärelä, T., Määttä, K., \& Uusiautti, S. (2018). The challenges of parent-teacher collaboration in the light of hospital school pedagogy. Early Child Development and Care, 188(6), 709-722. https://doi.org/10.1080/03004430.2016.1230108.

Al Hakim, M. F. (2021). Peran guru dan orang tua: Tantangan dan solusi dalam pembelajaran berani pada masa pandemi COVID-19. Jurnal Pendidikan Sejarah Dan Humaniora, 1(1), 16-25. https://doi.org/10.24372/jr.v4i1.19677.

Aouad, J., \& Bento, F. (2020). A complexity perspective on parent-teacher collaboration in special education: Narratives from the field in Lebanon. Journal of Open Innovation: Technology, Market, and Complexity, 6(1). https://doi.org/10.3390/joitmc6010004.

Arifa, F. N., \& Prayitno, U. S. (2019). Peningkatan Kualitas Pendidikan: Program Pendidikan Profesi Guru Prajabatan dalam Pemenuhan Kebutuhan Guru Profesional di Indonesia. Jurnal Aspirasi, 10(1). https://doi.org/10.22212/aspirasi.v10i1.1229.

Bhavya, B., Gautam, G., \& Sumedha, M. (2021). Impact of covid-19 pandemic on education system. EPRA International Journal of Environmental Economics, Commerce and Educational Management. https://doi.org/10.36713/epra6363.

Borg, E., \& Pålshaugen, Ø. (2019). Promoting Students' Mental Health: A Study of Inter-professional Team Collaboration Functioning in Norwegian Schools. School Mental Health, 11(3), 476-488. https://doi.org/10.1007/s12310-018-9289-9.

Carrillo, C., \& Flores, M. A. (2020). COVID-19 dan pendidikan guru: tinjauan literatur tentang praktik belajar mengajar online. Jurnal Pendidikan Guru Eropa, 43(4), 466-487. https://doi.org/466-487. https: //doi.org/10.1080/02619768.2020.1821184.

Chowdhury, M. (2018). Emphasizing morals, values, ethics, and character education in science education and science teaching. MOJES: Malaysian Online Journal of Educational Science, 4(2), 1-16. https://files.eric.ed.gov/fulltext/EJ1095995.pdf.

Dangin, I. G. R. A. Y., Wiyasa, K. N., \& Adnyana, I. K. (2019). Kontribusi Konsep Diri Dan Peduli Sosial Terhadap Kompetensi Pengetahuan IPS Siswa. Media Komunikasi FPIPS, 18(1). https://doi.org/10.23887/mkfis.v18i1.22240.

Deliviana, E., Maria Helena Erni, Putri Melina Hilery, \& Novi Melly Naomi. (2021). Pengelolaan Kesehatan Mental Mahasiswa Bagi Optimalisasi Pembelajaran Online di Masa Pandemi Covid-19. Jurnal Selaras: Kajian Bimbingan Dan Konseling Serta Psikologi Pendidikan, 3(2). https://doi.org/10.33541/jsvol2iss1pp1.

Dewi, E. R., \& Alam, A. A. (2020). Transformation model for character education of students. Cypriot Journal of Educational Sciences, 15(5). https://doi.org/10.18844/CJES.V15I5.5155.

Drane, C., Vernon, L., \& Shea, S. O. (2020). The impact of ' learning at home ' on the educational outcomes of vulnerable children in Australia during the covid-19 pandemic. In Literature Review prepared by the National Centre for Student Equity in Higher Education. Curtin University, Australia. https://www.ncsehe.edu.au/wp-content/uploads/2020/04/NCSEHE_V2_Final_literaturereviewlearningathome-covid19-final_30042020.pdf. 
Israhadi, E. . (2020). Dampak Sosial Keadaan Kahar dan Akibat Penetapan Status Bencana Covid 19 terhadap Pembelajaran UU Ketenagakerjaan. Jurnal Penelitian Pendidikan Ilmu Sosial, 11(4), 28-51.

Karakaya, F., Adıgüzel, M., Üçüncü, G., Çimen, O., \& Yilmaz, M. (2021). Teachers' views towards the effects of covid-19 pandemic in the education process in Turkey. Participatory Educational Research, 8(2), 17-30. https://doi.org/10.17275/per.21.27.8.2.

Kim, K., Harris, C. J., \& Pham, L. (2018). How Character Education Impacts Teachers. International Journal of Multidisciplinary Perspectives in Higher Education, 3(1). https://doi.org/10.32674/jimphe.v3i1.632.

Laili, F. M., \& Nuryono, W. (2015). Penerapan Konseling Keluarga Untuk Mengurangi Kecanduan Game Online Pada Siswa. 05, 9.

Liu, C. H., \& Doan, S. N. (2020). Psychosocial Stress Contagion in Children and Families During the COVID19 Pandemic. Clinical Pediatrics, 59(9-10), 853-855. https://doi.org/10.1177/0009922820927044.

Lonto, A. L., Wua, T. D., Pangalila, T., \& Sendouw, R. (2018). Moral work, teaching profession and character education in Forming Students' Characters. International Journal of Engineering and Technology(UAE), 7(4). https://doi.org/10.14419/ijet.v7i4.28.22560.

Miles, M. B., Huberman, A. M., \& Saldana, J. (2014). Qualitative Data Analysis + the Coding Manual for Qualitative Researchers. In Sage Publication (Vol. 1, Issue 4). Sage publication.

Muchsini, B., \& Siswandari. (2020). Class culture and the academic stress of digital natives generations. Cakrawala Pendidikan, 39(1), 102-110. https://doi.org/10.21831/cp.v39i1.26910.

Mulia, K., Hurley, P. \& Macklin, S. (2020). COVID-19, stres kerja, dan kerentanan pelajar di Australia. Institut Mitchell Untuk Kebijakan Pendidikan Dan Kesehatan Di Universitas Victoria, 1(1). https://doi.org/10.22201/ceiich.24485705e.2013.1.46541.

Mumpuniarti, M., Handoyo, R. R., Pinrupitanza, D. T., \& Barotuttaqiyah, D. (2020). Teacher's pedagogy competence and challenges in implementing inclusive learning in slow learner. Cakrawala Pendidikan, 39(1), 217-229. https://doi.org/10.21831/cp.v39i1.28807.

Myende, P. E., \& Nhlumayo, B. S. (2020). Enhancing parent-teacher collaboration in rural schools: parents' voices and implications for schools. International Journal of Leadership in Education. https://doi.org/10.1080/13603124.2020.1731764.

Niraha, W., Arya, Y., Parmiti, D. P., \& Yudiana, K. (2020). Pengaruh Model Think Pair Share Berbasis Tri Hita Karana Terhadap Sikap Peduli Sosial dan Kompetensi Pengetahuan IPA. Jurnal Adat Dan Budaya Indonesia, 1(1). https://doi.org/10.23887/jabi.v1i1.29024.

Nurhidayati, N., \& Indrawadi, J. (2020). Pembinaan Sikap Peduli Sosial Siswa Melalui Kegiatan Pramuka Di SMP Negeri 10 Padang. Journal of Civic Education, 3(1). https://doi.org/10.24036/jce.v3i1.330.

Paul, S. A. S., Hart, P., Augustin, L., Clarke, P. J., \& Pike, M. (2020). Parents' perspectives on home-based character education activities. Journal of Family Studies. https://doi.org/10.1080/13229400.2020.1806097.

Rahmawati, Ni'matul, L., Yunus, \& Maryam, S. (2020). Pramuka Sebagai Wadah Meningkatkan Nilai Karakter Peduli Sosial. ASANKA: Journal of Social Science And Education, 1(2). https://doi.org/10.21154/asanka.v1i2.2208.

Setiadi, R., Gandini, A. L. A., \& Kalsum, U. (2020). Parenting Skill Meningkatkan Pengetahuan Orangtua tentang Pembentukan Karakter Disiplin Anak Prasekolah. Poltekita : Jurnal Ilmu Kesehatan, 14(1). https://doi.org/10.33860/jik.v14i1.41.

Setyaningrum, Y., Rais, R., \& Setianingsih, E. S. (2020). Peran Guru Kelas dalam Pembentukan Karakter Disiplin pada Siswa. Jurnal Ilmiah Pendidikan Profesi Guru, 3(3), 520. https://doi.org/10.23887/jippg.v3i3.29752.

Singh, B. (2019). Character education in the 21st century. Journal of Social Studies (JSS), 15(1). https://doi.org/10.21831/jss.v15i1.25226.

Spinelli, M., Lionetti, F., Pastore, M., \& Fasolo, M. (2020). Parents' Stress and Children's Psychological Problems in Families Facing the COVID-19 Outbreak in Italy. Frontiers in Psychology, 11, 1713. https://doi.org/10.3389/fpsyg.2020.01713.

Sukarman, S. (2020). Sinergitas peran tri pusat pendidikan dalam pembelajaran berbasis daring di masa pandemi covid-19. MAGISTRA: Media Pengembangan Ilmu Pendidikan Dasar Dan Keislaman, 11(2). https://doi.org/10.31942/mgs.v11i2.3940.

Sutarini, Y. C. N., Priyoyuwono, P., \& Armstrong, T. (2015). Penanaman Nilai Karakter Tanggung Jawab Dan Kerja Sama Terintegrasi Dalam Perkuliahan Ilmu Pendidikan. Jurnal Pendidikan Karakter, 4(2), 213-224. https://doi.org/ 10.21831/jpk.v0i2.2797. 
Wahyuni, E. N., Aziz, R., Wargadinata, W., \& Efiyanti, A. Y. (2021). Investigation of Primary School Teacher Readiness in Online Learning during the Covid-19 Pandemic. Madrasah: Jurnal Pendidikan Dan Pembelajaran Dasar, 13(2), 97-113. https: //doi.org/10.18860/mad.v13i2.11343.

Waya, R. D., \& Siti, S. I. (2017). Kecerdasan Emosi dan Perilaku Agresi di Social Media Pada Remaja. Jurnal Psikologi Teori Dan Terapan, 7(2). https://doi.org/10.26740/jptt.v7n2.p82-87.

Wijayanto, S., Handani, D. F., Wardana, A. E., \& Hajron, K. H. (2020). Aktivitas di Sekolah Diliburkan saat Pendemi Covid-19: Bagaimana Pembelajaran yang Dilakukan? Jurnal Bidang Pendidikan Dasar, 4(2). https://doi.org/10.21067/jbpd.v4i2.4461.

Yuliyanto, A., Fadriyah, A., Yeli, K. P., \& Wulandari, H. (2018). Pendekatan Saintifik Untuk Mengembangkan Karakter Disiplin Dan Tanggung Jawab Siswa Sekolah Dasar. Metodik Didaktik, 13(2), 87-98. https://doi.org/10.17509/md.v13i2.9307. 